\title{
The Contribution of Brain CT Findings in predicting Stroke Patients' Prognosis for Activities of Daily Living
}

\author{
Tomoyoshi OTsukA*
}

\begin{abstract}
Purpose: The merit of brain CT findings for ADL prognosis in stroke patients is as yet undetermined due to inaccurate evaluation. I supposed that a more accurate evaluation might increase the precision of ADL prediction. Therefore, I examined whether or not a prediction method using an impairment scale, an ADL scale and brain CT findings using an original, newly devised evaluation method enhanced the prediction of ADL prognosis for subacute stroke patients. Methods: The subjects were 200 stroke patients (126 males and 74 females, average age $62.4 \mathrm{y} / \mathrm{o}$ ). They were comprised of cerebral hemorrhage and cerebral infarction patients. Subarachnoid hemorrhage patients were excluded due to the artifacts on their brain CTs. The brain CT findings were originally classified into 34 areas and checked to determine if there were lesions in each area. The Stroke Impairment Assessment Set (SIAS) and the Functional Independence Measure (FIM) were measured at admission and discharge. The total FIM score of 13 motor items at discharge was predicted using an artificial neural network model in 133 patients with 2 patterns of independent variables. The first pattern (non-CT pattern) included the SIAS score of 5 motor items, 4 sensory items, 2 trunk items and the FIM score of all the 18 items at admission. The second pattern (CT pattern) included the SIAS, the FIM scores (same items as non-CT pattern) plus the brain CT findings. Another 67 patients' data were applied to the created network and the correlation coefficients between the observed and the predicted total FIM scores of 13 motor items at discharge were calculated. Result: The correlation coefficient using the CT patterns was 0.837 and was higher than when the $\mathrm{CT}$ patterns were excluded. Conclusion: The brain CT findings using this original and accurate evaluation method may increase the precision of ADL prediction at discharge in stroke patients. (Jpn J Rehabil Med $2003 ; 40: 443-452$ )
\end{abstract}

要 旨：脳卒中患者 200 名を対象に, $\mathrm{ADL}$ 予後を, リハビリテーション病院に入院時の Stroke Impairment Assessment Set を用いた機能障害評価と Functional Independence Measure を用いた ADL 評価から予測した方法と，さらに頭部 CT 所見を加えて予測した方法を比 較し，頭部 CT 所見が ADL 予後予測に有用か検討した．頭部 CT は，機能局在も考慮して全 脳を 34 領域に分け, 各領域の病巣の有無を評価した。統計処理はニューラルネットワークを 用いた。その結果，頭部 CT 所見を加えることが，予後予測の精度を向上させ，頭部 CT 所見 が脳卒中予後予測に有用である可能性が示された。（リ八医学 $2003 ； 40 ： 443-452$ )

Key words: 脳卒中 (stroke), 予後予測 (functional prognosis), CT (computed tomography), ADL (activities of daily living), ニューラルネットワーク (artificial neural network)

2002 年 9 月 26 日受付, 2003 年 5 月 16 日受理

*慶應義塾大学医学部リハビリテーション医学教室/テ 160-8582 東京都新宿区信濃町 35

Department of Rehabilitation Medicine, Keio University School of Medicine

$$
\text { リハビリテーション医学 VOL. } 40 \text { NO. } 72003 \text { 年 } 7 \text { 月 }
$$




\section{はじめに}

脳卒中患者の日常生活動作 (Activities of Daily Living, 以下 ADL) の予後予測は, 適切なリハビリ テーション（以下，リハ）を適切な治療期間で行うた めに重要である，予後予測を主題とした論文は，1980 年に世界保健機関が定めた国際障害分類 ${ }^{1}{ }^{2}$ に基づく機 能障害 (Impairment), 能力低下 (Disability), 社会 的不利（Handicap）の 3 つの階層のさまざまな評価 法や病態などを用いて生命予後や機能予後, ADL 予 後を予測している報告がある。

我が国では以前より，脳卒中患者の機能障害評価は Brunnstrom Stage ${ }^{2)}$ が，能力低下の中の ADL 評価 については Barthel Index ${ }^{3)}$ が使用されることが多か ったが，最近では，機能障害評価は Stroke Impairment Assessment Set ${ }^{4)}$ (以下 SIAS）を，ADL 評価 は機能的自立度評価法 (Functional Independence Measure，以下 $\mathrm{FIM}^{5)}$ ) を用いた報告もなされてい る.

これまでの ADL 予後予測に関する報告は，リハ開 始時の ADL 評価から退院時やある一定期間後の ADL を予測している報告が多い6 11). 一方で, 病変 の部位や大きさを評価できる頭部 CT 所見を取り入れ た予後についての検討は少ない. 1979 年に Miller ${ }^{22}$ は頭部 CT が正常あるいは病変が小さい方が移乗・移 動での介助量が少ないと報告している，山海ら ${ }^{13)}$ は, 発症後 3 週間以内の頭部 CT 上の高吸収域あるいは低 吸収域の有無とその病巣部位から脳出血（脳室穿破 有・脳室穿破無), 〈も膜下出血, 脳梗塞 (穿通枝系 脳梗塞・皮質枝系脳梗塞), 異常所見なしの 6 つに分 類し, 発症後 1 年と 3 年の要介助状況（全介助または ベッド上生活自立）について検討し，脳室穿破有の脳 出血あるいは皮質枝系脳梗塞で，要介護状況になる危 険性が高いと指摘している. Chaudhuri ら ${ }^{14)}$ は，脳 梗塞患者の頭部 CT を異常所見なし，表在性小病変 (単一葉内), 表在性大病変 (複数葉), 深部病変, 混 合病変, 両側病変に分類し, 機能自立するのは, 異常 所見なしあるいは表在性小病変患者であると報告して いる. Saeki ら ${ }^{15)}$ は頭部 CT 上の病変の有無を左右 の前頭葉, 後頭葉, 側頭葉, 頭頂葉, 被殼, 視床, 脳 幹，小脳で調查し，リ八病院退院時の Barthel index を重回帰分析で解析したが，説明率が低く，病変部位 以外の要素の影響を指摘している. Beloosesky ら ${ }^{16)}$
は脳梗塞患者 56 名を対象に, $\mathrm{ADL}$ 予後予測を行い, 中大脳動脈領域の脳梗塞患者では, 病巣が大きいほど $\mathrm{ADL}$ 予後は不良だが，深部病変の患者では病巣の大 きさと ADL 予後に有意な関係は認めなかったとして いる. Hertanu ら ${ }^{17)}$ は，頭部 CT 上，前頭葉，側頭 葉，頭頂葉，錐体路，基底核，内包，後頭葉，多発 性，脳幹に分け，ADLを Barthel index で評価し， リ八病院退院時の Barthel index を予測する因子とし ては，入院時の Barthel index が最良であり，頭部 CT 所見は有用ではないとしている，以上のように， 現在までのところ，頭部 CT 読影法もおおまかな分類 であり，頭部 CT の ADL 予後予測に対する有用性に ついては，一定の評価は得られていない.

そこで本研究では，頭部 CT をより詳細に評価する ことで脳卒中患者の $\mathrm{ADL}$ 予後予測の精度が向上する と推測し，SIASによる機能障害評価と FIM による $\mathrm{ADL}$ 評価に頭部 CT 所見を加えて，ニューラルネッ トワークによる統計処理を行って検討したところ，興 味ある知見が得られたので若干の考察を加えて報告す る.

\section{対 象}

対象は, 1993 年から 1994 年にかけて, 脳卒中の急 性期を脱し, 慶應義塾大学病院りハ科及びその関連病 院にリ八治療目的で入院した初発脳出血あるいは脳梗 塞患者のうち，順次 200 名を対象に検討した。なお， くも膜下出血患者については, 動脈瘤術後クリップが アーチファクトを起こし，頭部 CT 読影に支障をきた す可能性があるために，対象から除外した，対象者の 性別は男性 126 名，女性 74 名であった。年齢は 32 92 歳, 平均 62.4 歳であった. 診断は脳梗塞 118 名, 脳出血 82 名であった。麻痺側は右片麻痺が 103 名, 左片麻痺が 97 名であった.リ八治療は, 理学療法, 作業療法および言語療法を必要に応じて組み合わせて 行った.リ八病院入院までの期間は，発症から0〜 166 日, 平均 50.7 日であった. 発症から 0 日で入院 した患者は，急性期病院のリ八科に入院したものであ る.入院期間は，13〜298 日，平均 88.7 日であった。

\section{方法}

\section{1. リ八評価 \\ 1) 機 能 評価}

リハ病院入院時に，SIAS により機能障害を評価し 
た. SIAS は, 麻痺側運動機能, 筋緊張, 感覚機能, 関節可動域, 非麻痺側運動機能, 疼痛, 体幹機能, 視 空間認知, 言語機能の 9 種の機能障害に分類される 22 項目からなり, 各項目とも 0 点から 3 あるいは 5 点満点で評価し, 合計点は $0 \sim 76$ 点（健常）になる評 価法である. SIAS の特長として, 多面的な脳卒中機 能障害の評価項目として必要かつ最小限の項目を含 み, 検者一人で簡単に短時間に評価可能で, 各項目が 単一のテストによって評価でき, 非麻痺側機能を含ん だ総合評価セットであるといえる.

本研究では, 予測変数 (独立変数) として, 全 22 項目中麻痺側機能を代表する運動機能（上肢近位テス 卜，上肢遠位テスト，下肢近位テス卜（股関節屈曲テ ストと膝伸展テスト), 下肢遠位テストの 5 項目で各 項目 5 点満点), 感覚機能 (上下肢の触覚および位置 覚の 4 項目で各項目 3 点満点), 体幹機能（腹筋力と 座位バランス（垂直性）の 2 項目で各項目 3 点満点） の 11 項目の素点を用いた。

\section{2) $\mathrm{ADL}$ 評価}

リ八病院入退院時の $\mathrm{ADL}$ 評価を, FIMを用いて 行った. FIM は, 介護量の測定を目的として, 運動 項目と認知項目の 2 つの領域に分類される全 18 項目 を介護の度合いに応じて 1 から 7 点の 7 段階で評価 し, 合計点は 18 点（すべての項目で全介助）から 126 点（すべての項目で自立）になる評価法である. FIM の特長は, ADLの必要最小限の項目が集めら れ, ADLの運動面だけでなく, 認知面の評価も含ま れる点にある。

本研究では, 予測のための変数 (独立変数) とし て, リ八病院入院時の FIM 全 18 項目の素点を用い た。また, 退院時の FIM 運動項目 13 項目合計点を 予測される変数 (従属変数) とした. 独立変数として 入院時評価を全 18 項目採用したのは, 認知面のリハ 訓練への影響を考慮したためであり, 従属変数とし て, 運動項目 13 項目合計点としたのは, 全 18 項目合 計点では, 同点数でも運動・認知項目の分布が異なる ために, 運動項目 13 項目合計点に限定した。

\section{2. 頭部 CT 所見}

頭部 CT 所見は, 橋 - 小脳 (虫部 - 半球) - 中脳・ 前頭葉 $($ 底部・内側部・凸部・白質部 $) \cdot$ 尾状核・視 床 (外側部 - 内側部) - 被殼 $\cdot$ 内包（前脚・後脚前 部・後脚中部・後脚後部) - 外包 $\cdot$ 島 $\cdot$ 海馬 - 側頭葉 (前部・後部)・シルビウス前後部・後頭葉（内側部・
外側部）・放線冠（前部・中部・後部）・頭頂葉（前 部・後部) ・ 中心前回・中心後回・角回・後頭回の 34 領域に分割して, その領域に病巣が存在するか否かを 評価した. 34 領域の頭部 CT 上の定義を図 1 に示す. 34 領域への分割については, 機能解剖を考慮しつつ, 脳の大きさや立体構造の個人差によって, 撮影された 画像断面が必ずしも同一領域を写し出さないことも考 慮して決定した。読影に用いた頭部 CT は, 発症後 1 カ月以降に撮影されたものとした。評価法は, 各領域 において病巣が存在すれば 1 , 存在しなければ 0 とし た.

\section{3. 頭部 CT 評価法の妥当性}

予備実験として, 本研究で用いた頭部 CT 評価法の 妥当性の検討を行った. 対象 200 名の中から, 無作為 に 25 名を抽出し, 読影に 7 年以上携わった 2 名の検 者が個別に 25 名の頭部 CT を読影し，34 領域におけ る病巣の有無を評価し, その一致率 $x$ を求め, 再現 性を検討した。

\section{4. ニューラルネットワークを用いた ADL 予後 予測}

頭部 CT 所見の ADL 予後予測における有用性を検 討するために，ニューラルネットワークによる統計処 理を行った.

ニューラルネットワーク ${ }^{18)}$ とは, 生体のシナプス 間の情報処理を模し, 図 2 のように入力層, 中間層, 出力層の 3 層構造を仮定し, 既存のデー夕項目を神経 細胞に相当する「節 (node)」とし, 入力層の node にデータ (独立変数) を繰り返し入力し, 各層間のつ ながりの強さを変えながら，より適切な出力（従属変 数）が得られるように学習させた統計モデルである. 実際の処理方法は，ネットワークを構築するための対 象（予測群）のデー夕群を入力層に入力し学習させ, 構築されたネットワークの普遍性を検証するための対 象（検証群）のデー夕群を入力層に入力し, 出力層か ら出力したデー夕（予測值）を検証群の実際のデー夕 （実際值）と比較検討するものである，同一対象群で 予測・検証する際には, 対象群をお扔よそ 2 対 1 に分 割し，それぞれを予測群と検証群に設定する。

上記の方法に従い, 対象 200 名を順次検証群, 予測 群, 予測群と振り分けて, 予測群 133 名と検証群 67 名分割した。なお，予測群と検証群の構成について は，表 1 に示すとおりである.

退院時の FIM 運動項目 13 項目合計点予測を, 前 


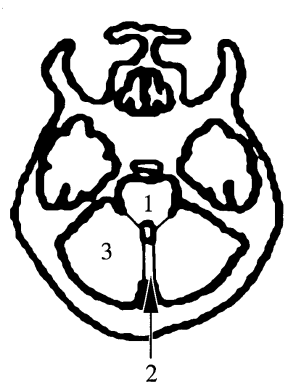

$20 \cdot 2$

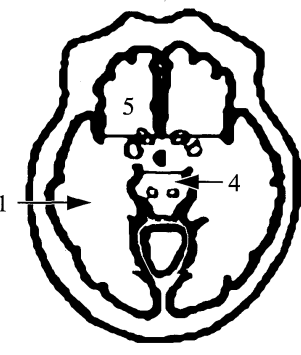

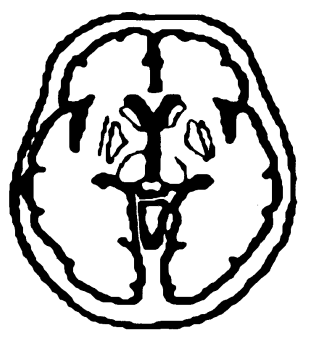
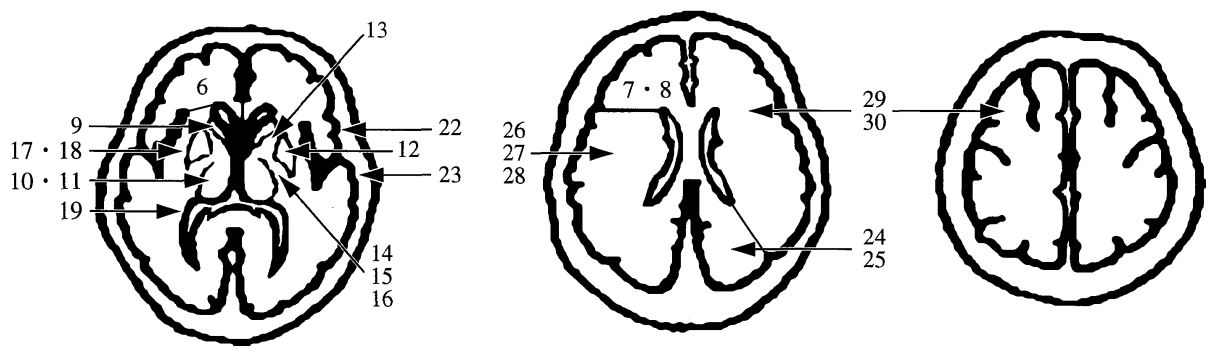

1. 橋：小脳虫部の見えるスライスで小脳の前側脳幹部

2. 小脳虫部：後頭隆起と第四脳室の両端を結ぶ線の内側

3. 小脳半球：小脳虫部を除く小脳

4. 中脳：橋より上部で, 視床より下部の脳幹部

5. 前頭葉底部：脳幹部（橋・中脳）の見えるスライスの前頭葉（中心溝より前側）

6. 前頭葉内側部：底部と凸部の間の前頭葉

7. 前頭葉凸部：基底核が見えないスライスでの前頭葉（シルビウス裂より前）

8. 前頭葉白質部：前頭葉白質部分

9. 尾状核：側脳室前角と内包前脚との間

10. 視床外側：側脳室と内包後脚（白質部分）との間の外側二分の一

11. 視床内側：側脳室と内包後脚（白質部分）との間の内側二分の一

12. 被殼：内包より外側，外包より内側の（灰白質部分）部分

13. 内包前脚：尾状核の外側の白質部分で，内包膝より前部

14. 内包後脚前部：視床と被殼の間の白質部分スライスで，内包膝より最後部を三等分した最前部

15.内包後脚中部：14.と同じスライスで，内包膝より最後部を三等分した中部

16. 内包後脚後部：14.と同じスライスで, 内包膝より最後部を三等分した最後部

17. 外包：被款より外側の白質部分

18. 島：シルビウス裂の突き当たり，外包より外側の灰白質部分

19. 海馬：側脳室後角に接する側頭葉部分

20. 側頭葉前部：シルビウス裂より後方, 側脳室の後角先端の延長部までの部分の前二分の一 ただし上方は側脳室の見えるまで

21. 側脳室後部：20.と同じスライスで，後二分の一

22. シルビウス前部：シルビウス裂（外側溝前枝）に接した側頭葉部分 ただし被殼の見えるスライスで

23. シルビウス後部：シルビウス裂（外側溝後枝）に接した側頭葉部分 ただし側脳室の見えるスライスで

24. 後頭葉内側部：大脳鎌部分と側脳室後角の延長線の間の内側二分の一

25. 後頭葉外側部：大脳鎌部分と側脳室後角の延長線の間の外側二分の一

26. 放線冠前部：被殸の見えるスライスより上方かつ側脳室の見えるスライスで，尾状核の外側か ら外側溝後枝の最深部までの白質部分で，前方より後方までを三等分した最前部

27. 放線冠中部：26.の三等分した中部

28. 放線冠後部：26.の三等分した最後部

29. 頭頂葉前部：中心溝より後方, 上方で, 後頭葉でない部分の前二分の一

30. 頭頂葉後部：中心溝より後方, 上方で, 後頭葉でない部分の後二分の一

31. 中心前回：中心溝直前の頭回

32. 中心後回：中心溝直後の頭回

33. 角回：側脳室の見えなくなったスライスで, 上側頭溝の後方の頭回

34. 後頭回：大脳鎌部に接した最後方の頭回

図 1 頭部 CT 上の領域分割 


\section{出力層}

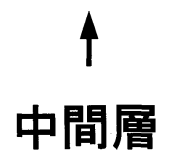

入力層

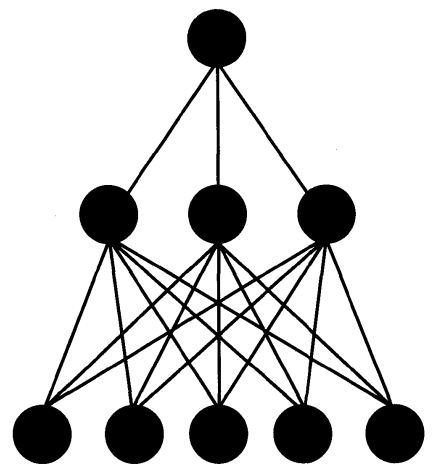

例 : 退院時のFIM得点

例 : SIAS得点、FIM得点

図 2 ニューラルネットワーク模式図

入力層に予測のための従属変数を入力し, 繰り返し統計処理すること で，適切な出力を行う.

表 1 ニューラルネットにおける予測群・検証群の 構成

\begin{tabular}{|c|c|c|}
\hline & 予測群 $(n=133)$ & 検証群 $(n=67)$ \\
\hline 性別 男性 & 86 & 40 \\
\hline 女性 & 47 & 27 \\
\hline 年齢 & $\begin{array}{c}32 \sim 92 \text { 歳 } \\
\text { (平均 } 63.3 \text { 歳) }\end{array}$ & $\begin{array}{c}36 \sim 91 \text { 歳 } \\
\text { (平均 } 60.6 \text { 歳) }\end{array}$ \\
\hline $\begin{array}{l}\text { 診断 脳梗塞 } \\
\end{array}$ & 79 & 39 \\
\hline 脳出血 & 54 & 28 \\
\hline \multirow[t]{2}{*}{ 麻痺側＼cjkstart右 } & 66 & 37 \\
\hline & 67 & 30 \\
\hline $\begin{array}{l}\text { 入院時 SIAS } \\
11 \text { 項目合計点 }\end{array}$ & $\begin{array}{c}0 \sim 43 \text { 点 } \\
\text { (平均 } 26.9 \text { 点) }\end{array}$ & $\begin{array}{c}2 \sim 43 \text { 点 } \\
\text { (平均 } 27.3 \text { 点) }\end{array}$ \\
\hline $\begin{array}{l}\text { 退院時 SIAS } \\
11 \text { 項目合計点 }\end{array}$ & $\begin{array}{c}9 \sim 43 \text { 点 } \\
\text { (平均 } 30.8 \text { 点) }\end{array}$ & $\begin{array}{c}8 \sim 43 \text { 点 } \\
\text { (平均 } 31.1 \text { 点) }\end{array}$ \\
\hline \multirow{2}{*}{$\begin{array}{l}\text { 入院時 FIM 運動 } \\
13 \text { 項目合計点 } \\
\text { 入院時 FIM 認知 } \\
5 \text { 項目合計点 }\end{array}$} & $\begin{array}{c}13 \sim 91 \text { 点 } \\
\text { (平均 } 65.1 \text { 点) }\end{array}$ & $\begin{array}{c}14 \sim 89 \text { 点 } \\
\text { (平均 } 70.4 \text { 点) }\end{array}$ \\
\hline & $\begin{array}{c}5 \sim 35 \text { 点 } \\
\text { (平均 } 25.1 \text { 点) }\end{array}$ & $\begin{array}{c}9 \sim 35 \text { 点 } \\
\text { (平均 } 27.1 \text { 点) }\end{array}$ \\
\hline \multirow{2}{*}{$\begin{array}{c}\text { 退院時 FIM 運動 } \\
13 \text { 項目合計点 } \\
\text { 退院時 FIM 認知 } \\
5 \text { 項目合計点 }\end{array}$} & $\begin{array}{c}37 \sim 91 \text { 点 } \\
\text { (平均 } 77.8 \text { 点) }\end{array}$ & $\begin{array}{c}33 \sim 89 \text { 点 } \\
\text { (平均 } 75.1 \text { 点) }\end{array}$ \\
\hline & $\begin{array}{c}5 \sim 35 \text { 点 } \\
\text { (平均 } 30.2 \text { 点) }\end{array}$ & $\begin{array}{l}10 \sim 35 \text { 点 } \\
\text { (平均 } 32.2 \text { 点) }\end{array}$ \\
\hline
\end{tabular}

記のようにリハ病院入院時の SIAS 11 項目と FIM 全 18 項目の各素点を予測変数とする方法（non-CT 法） と, その 2 つ評価法に頭部 CT 所見を加えた方法 （CT 法）とで，ニューラルネットワークを予測群で 構築し，検証群に応用して，その予測值と実際値との 相関計数を求めた。

統計処理は, SkilTran ${ }^{\mathrm{TM}}$ (千代田化工建設社製, 横浜）を用いて行った.

\section{結果}

\section{1. 入院時 SIAS}

入院時 SIAS の項目別得点分布を図 3 に示す．運動 機能のうち, 上肢近位, 下肢近位 (股関節屈曲・膝伸 展), 下肢遠位の各項目については 4 点（テスト運動 は可能だが，軽度のぎこちなさを認める）が，それぞ れ 200 名中 60 名 $(30.0 \%), 75$ 名 $(37.5 \%), 70$ 名 (35.0\%)，59名 (29.5\%) と最も多かった. しかし, 下肢遠位については, 全く動かない 0 点が 50 名 （25.0\%）と 4 点に次いで多かった。上肢遠位は, 全 く動かない 0 点が 54 名 $(27.0 \%)$ と最も多く, 次い でわずかな動きを認める 1 点が 49 名 $(24.5 \%)$ で重 度障害対象者が多かった。

一方, 上下肢触覚, 上下肢位置覚, 座位バランス (垂直性), 腹筋力については, それぞれ76名 $(38.0 \%), 85$ 名 $(42.5 \%), 111$ 名 $(55.5 \%), 112$ 名 (56.0\%), 159 名 (79.5\%), 79 名 (39.5\%) と正常 (3 点) が最も多かった.

入院時 SIAS 11 項目合計点は 43 点満点で, $0 \sim 43$ 点（平均 27.0 点）であった. 満点は 3 名であった. また, 退院時の SIAS 11 項目合計点は, 8〜43 点（平 均 30.9 点) で, 平均で 3.9 点の改善を認めた. 満点 は 8 名であった。

\section{2. 入退院時 FIM}

入院時 FIM 18 項目別得点を図 4 亿示す.

運動項目のうち, 清拭・浴槽移乗・階段の各項目は 全介助 (0 点) が 77 名 $(38.5 \%) ， 85$ 名 $(42.5 \%) ， 141$ 名 $(70.5 \%)$, と多かったが, 食事・整容・排尿コン 


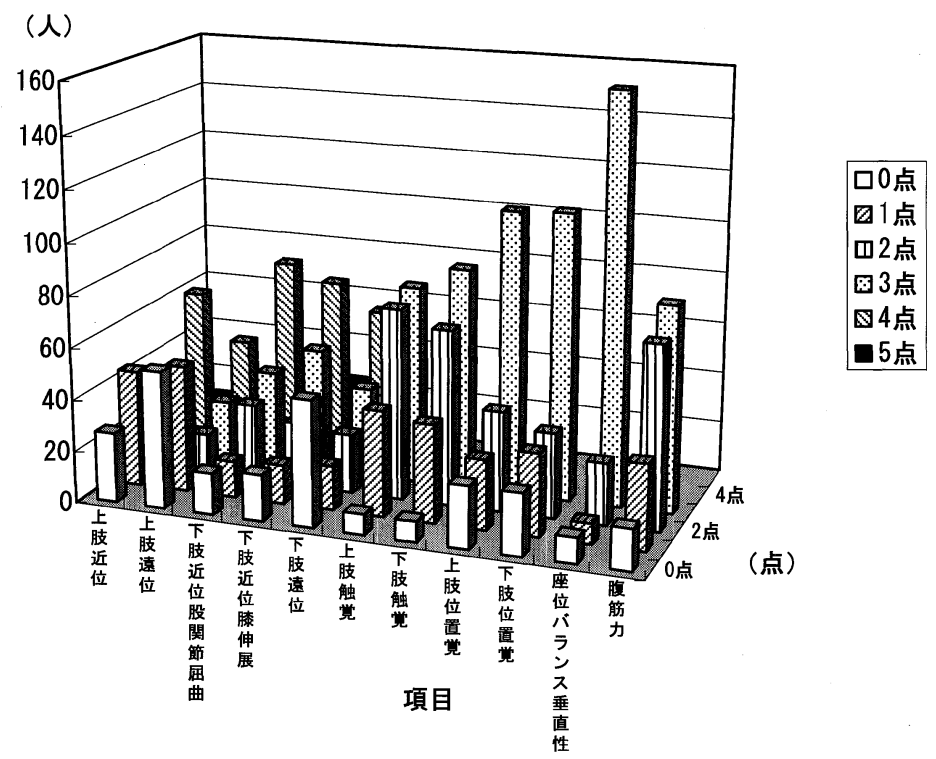

図 3 SIAS 分布

運動機能のうち，上肢遠位・下肢遠位は 0 点（重度障害）も多い. 上肢近位・下肢近位は 4 点（軽度のぎこちなさを認める）が多い.

上下肢触覚・位置覚・体幹機能は 3 点（正常）が多い.

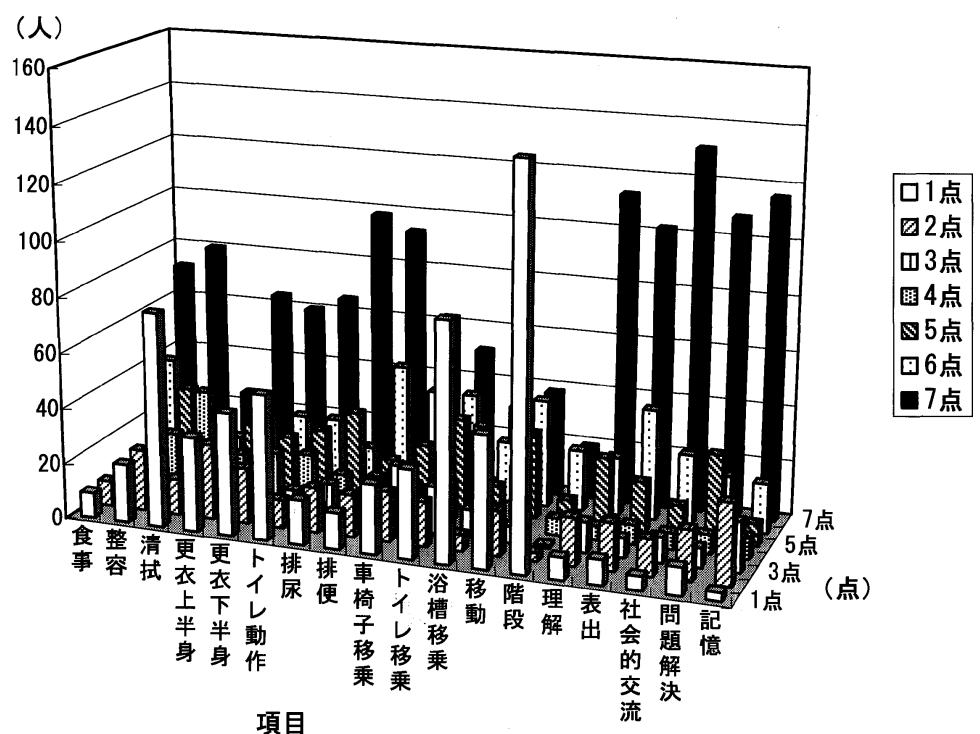

図 4 入院時 FIM

運動項目のうち，食事・整容・排尿・排便については自立が多いが，清拭・浴槽 移乗・階段については全介助が多い。認知項目はいずれも自立が多い。

トロール・排便コントロールの各項目は自立（7点） がそれぞれ 72 名 $(36.0 \%) ， 80$ 名 (40.0\%)，98名 (49.0\%)，93名（46.5\%）と多かった。一方，認知 項目は理解, 表出, 社会的交流, 問題解決, 記憶は自
立がそれぞれ 113 名 (56.5)，102名 $(51.0 \%), 131$ 名 $(65.5 \%) ， 108$ 名 (54.0\%)，116名 (58.0\%) と いずれも自立が多かった。

入院時運動 13 項目合計点は $13 \sim 91$ 点（平均 66.9 
点), 認知 5 項目合計点は 5〜35 点（平均 25.8 点） で, 項目別平均は 5 点台で, 監視レベルであった。退 院時運動 13 項目合計点は 33 91 点 (平均 76.9 点), 認知 5 項目合計点は $5 \sim 35$ 点（平均 30.9 点）で, 項 目別平均は, 6 点台で, 修正自立レベルとなり, $\mathrm{ADL}$ 評価でも改善を認めた。

\section{3. 頭部 CT 評価法の妥当性}

表 2 に 2 名の検者間の頭部 CT 34 領域ごとの一致 率 $x$ を示す.一致率 $x$ は, 最低でも橋の 0.65 であっ た.また 34 領域中 22 領域では, 2 名の検者で病巣の 有無について完全に一致していた.

表 2 頭部 CT 所見の検者間一致率一覧

\begin{tabular}{|c|c|}
\hline$x$ 值 & 領 域 \\
\hline $\begin{array}{l}\text { 完全に一致 } \\
(x=1.00)\end{array}$ & 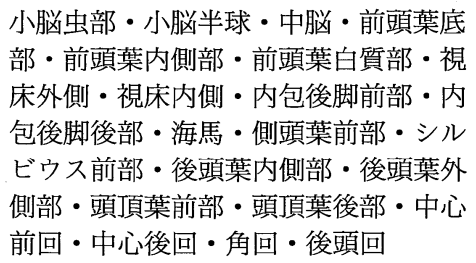 \\
\hline $\begin{array}{l}\text { ほぼ完全に一致 } \\
(x>0.81)\end{array}$ & 内包前脚・放線冠前部・放線冠中部 \\
\hline $\begin{array}{l}\text { 十分に一致 } \\
(x>0.61)\end{array}$ & $\begin{array}{l}\text { 橋 } \cdot \text { 前頭葉凸部 } \cdot \text { 尾状核・被殼 } \cdot \text { 内包 } \\
\text { 後脚中部 } \cdot \text { 外包島 } \cdot \text { 側頭葉後部 } \cdot \text { 放線 } \\
\text { 冠後部 }\end{array}$ \\
\hline
\end{tabular}

2 検者間で完全に一致した領域が 34 領域中 22 領域，ほ ほ完全に一致が 3 領域, 十分に一致が 9 領域であった。

\section{4. 頭部 CT 所見}

頭部 CT で病変の観察された部位の分布を図 5 に示 す。被殼・放線冠中部に病変を有する対象者が，200 名中それぞれ 113 名 (56.5\%)，111名 (55.5\%) と 多かった. 一方, 34 領域中 9 領域 (小脳虫部・前頭 葉底部・前頭葉白質部・海馬・シルビウス前後部・後 頭葉内外側部・後頭回）の病変を有する対象者は見ら れなかった。

単一の領域に病変を有した対象者は 200 名中 21 名 （10.5\%）であったのに対して, 複数の領域に病変を 有した対象者は 179 名 (89.5\%) で, 複数の領域にわ たり病変を有した患者が多かった。

5. ニューラルネットワークを用いた ADL 予後 予測

ニューラルネットワークを構築するにあたり, nonCT 法では入院時 SIAS 11 項目と入院時 FIM 全 18 項 目の素点のそれぞれを入力層の node とし, CT 法で はそれら 2 つ評価に頭部 CT の各領域のそれぞれを 入力層の node として, 予測群のデータを入力し, 退 院時 FIM 運動項目 13 項目合計点を出力とした. そ して, 構築されたニューラルネットワークに検証群の データを入力し, 退院時 FIM 運動項目 13 項目合計 点（予測值）を出力させ, 実際值と比較した.

その結果, 検証群における退院時 FIM 運動項目 13 項目合計点の予測值と実際值との相関計数は, non-

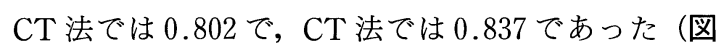
$6 \mathrm{a}, \mathrm{b})$. non-CT 法では, 退院時 FIM 運動項目 13

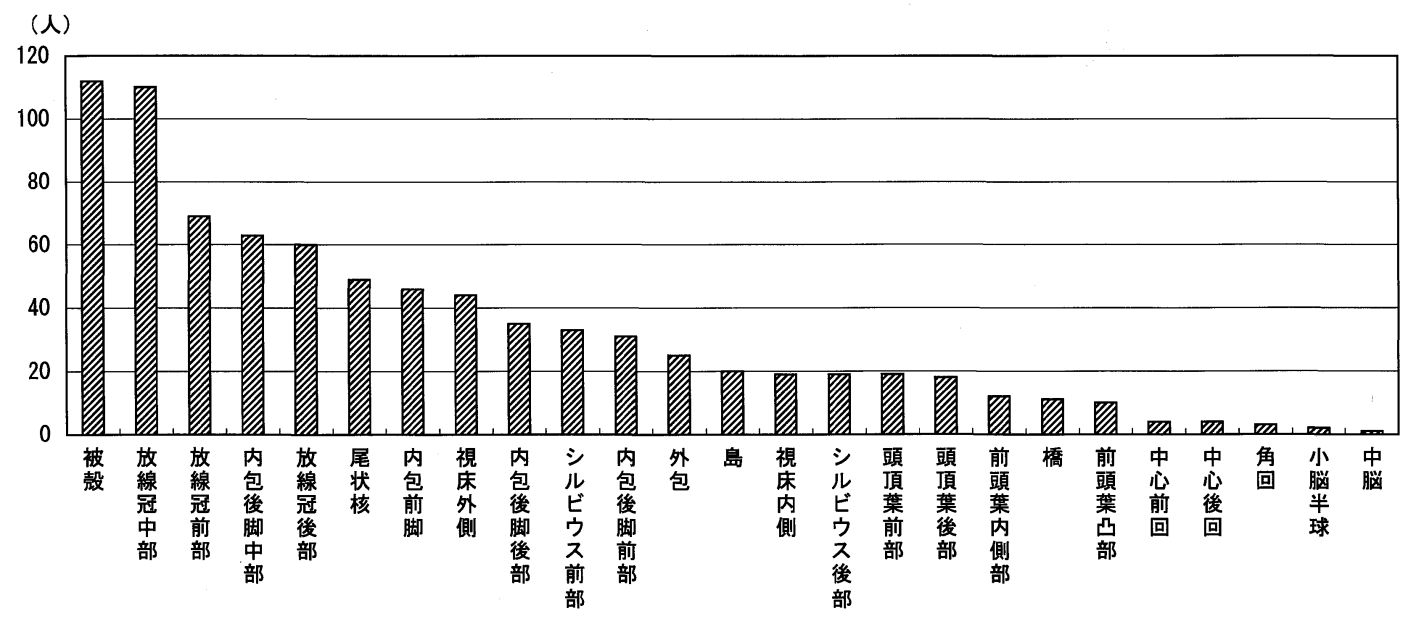

(部位)

図 5 頭部 CT 所見

病巣の確認された部位を示す，被殼・放線冠に病変を有する患者が多く見られた。 
(a)

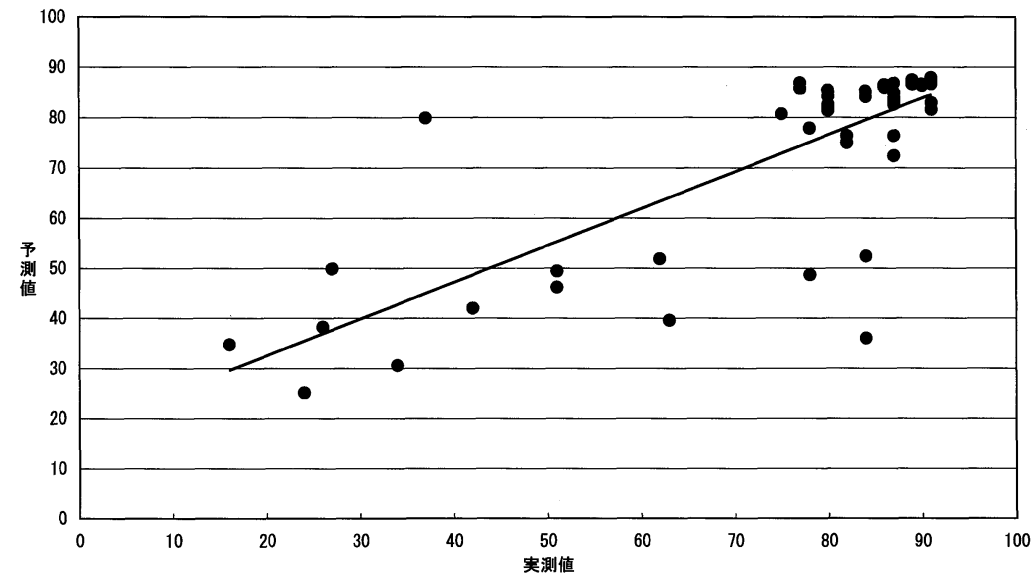

(b)

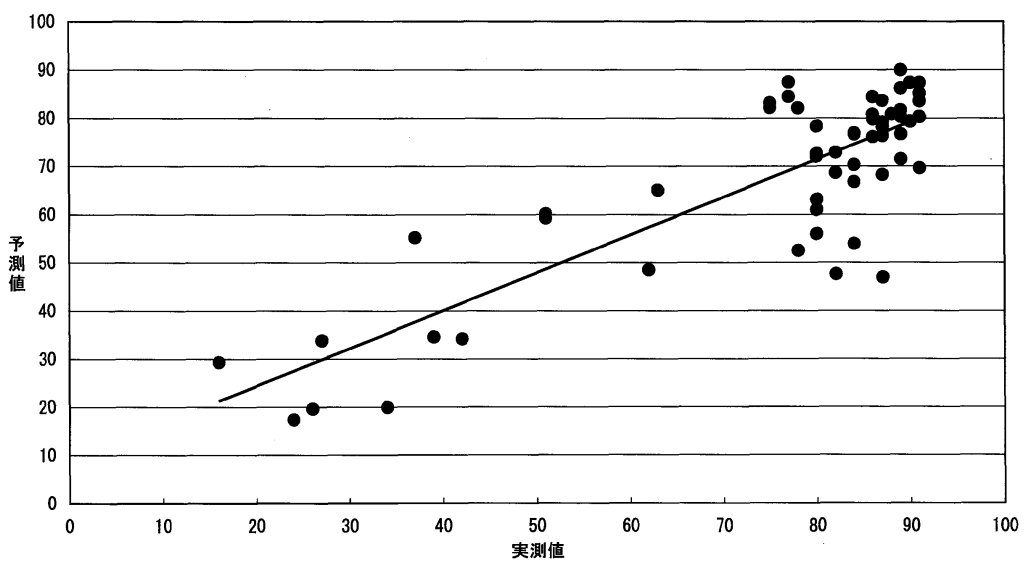

図 6 退院時 FIM 運動 13 項目予測值と実測值の関係

(a) non-CT 法 (SIAS と FIM から予測した場合) で，相関係数は 0.802 .

（b ） CT 法（SIAS と FIM，頭部 CT 所見から予測した場合）で，相関係数は 0.837.

項目合計点の実際值が 40 点以上の場合に予測值が低 くなる例が散見された。一方, CT 法では退院時 FIM 運動項目 13 項目合計点の実際值が 70 点以上の 場合に予測值と実際值の分布のばらつきが大きくなっ たが, non-CT 法のように低く予測される例は少なか った。 また, 予測群で構築したネットワークの入力層 に残った領域の中で, 中間層との結びつきの強かった 領域は, 放線冠, 内包後脚であった。

以上より, 脳卒中患者の ADL 予後予測の予測因子 に頭部 CT 所見を加えると, 予測精度が向上すること が示された。

\section{考察}

本研究は, 急性期治療を終え, リ八治療を開始した 初発脳卒中亜急性期の患者を対象としている.リハ治
療は, 各病院ともリ八専用病床があり, 個別訓練を中 心として, 入院期間中十分に行われた. しか儿, リ八 治療を開始する段階で，いかなる病院であっても，患 者の $\mathrm{ADL}$ 予後を予測することは, リ八医療を行う上 で重要かつ不可欠なことである。これまでのニューラ ルネットを用いた脳卒中患者の $\mathrm{ADL}$ 予後予測につい ては, Sonoda ら ${ }^{8)}$ が, 発症後 3 力月時の FIM 運動 項目合計点から 6 力月時の FIM 運動項目合計点を予 測し, 予測值と実際值の相関計数は 0.74 と高い相関 を示したと報告している. 本研究では, non-CT 法に おいて相関係数は 0.802 と同様に高い相関があること を示した。これは, 評価法として, 脳卒中による機能 障害や ADL 能力のより詳細な評価が可能な SIAS や FIM を用いたことが, 高い相関を示す結果になった と考えられる. しかし，さらに non-CT 法と比較して 
CT 法においては，相関係数が 0.837 と増加し，つま り, ADL 予後予測の精度がより向上し, 頭部 CT 所 見が脳卒中患者の ADL 予後予測に対して有用である 可能性が示唆された.これまでの頭部 CT 所見を用い た ADL 予後予測に関する報告と比較すると, 本研究 の特長として, 頭部 CT 画像をより詳細に評価するた めに, 全脳を 34 領域に分割し, 各領域の病変の有無 をチェックする方法を用いたが, この方法は, 病巣の 部位はもちろん, 病巣の大きさもチェックされる病巣 の数と範囲に反映している. 多発性脳梗塞のような患 者についても, 主たる病変とは別の領域に病変が存在 しても，その情報を利用することができる。また， 2

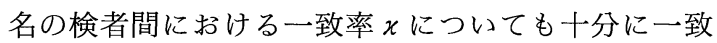
しているとされる值で, 評価法としては妥当と考えら れる. 予測群で構築したネットワークの入力層に残つ た領域の中で, 中間層との結びつきが強かった部位 は, 放線冠や内包後脚で, 錐体路に沿った領域である ことは, FIM 運動項目合計点には, 脳卒中患者の運 動機能が影響していることを示唆している. non-CT 法, CT 法いずれにおいても, FIM 運動 13 項目合計 点が高くなると, 予測值と実測值とのばらつきが大き くなったが, 合計点の低い患者も含めて統計処理した ために，その影響が反映された結果と考えられる。

しかし, 頭部 CT 画像は頭部磁気共鳴画像（Magnetic Resonance Imaging, 以下 MRI）に比べて, 画 像精度が劣る問題があるが, 当時患者の入院した複数 のリハ病院に MRI 機器が普及していなかったため CT 画像を用いた。

従来, 脳卒中患者の機能予後や $\mathrm{ADL}$ 予後予測に は, 重回帰分析が用いられることが多かった ${ }^{13,17)}$ が, 重回帰分析では, 線形のデータのみ処理が可能で, 予 測因子に制限があった。しかし，本研究で用いた二ュ ーラルネットワークでは, 非線形データの処理も可能 で, 多重共線性も問題とならない特徴がある。本研究 においては，頭部 CTを 34 領域に細分化すること， および統計処理手法としてニューラルネットワークを 用いることの双方が，FIM を用いた ADL 予後予測 の向上に寄与したと考えられる.

頭部 CT 所見が脳卒中患者の ADL 予後予測に有用 である可能性が示されたが, 今後の研究課題として は, 頭部 CT のような静止画像ではなく, 機能的 MRI 画像（Functional MRI）や脳磁図 (Magnetic Encephalography；MEG）などの機能的な画像を用
いた脳卒中患者の $\mathrm{ADL}$ 予後予測が必要と考えられ る.

稿を終えるにあたり，ご指導，ご高閲を賜った慶應義塾 大学医学部リハビリテーション医学教室千野直一教授に深 謝するとともに, 慶應義塾大学月が瀬リハビリテーション センター木村彰男教授, 藤田保健衛生大学七栗サナトリウ 厶園田茂教授, 東京専売病院リハビリテーション科堀田富 士子部長に感謝いたします。

\section{文 献}

1) International Classification of Impairment, Disabilities and Handicaps (ICIDH) : World Health Organization (WHO). Geneva, 1980

2) Brunnstrom $\mathrm{S}$ : Movement Therapy in Hemiplegia. Harper \& Row, New York, 1970

3) Mahoney FI, Barthel DW : Functional evaluation: the Barthel index. St Med J 1965 ; 14 : 61-65

4) 千野直一 編: 脳卒中患者の機能評価. SIAS と FIM の実際. シュプリンガー・フェアラーク, 東京, 1997

5) Fiedler RC, Granger CV : The Functional Independence Measure; a measurement of disability and medical rehabilitation. in Functional Evaluation of Stroke Patients (ed by Chino N, Melvin JL). Springer, 1996; pp 75-92

6) Anderson TP, Bourestom N, Greenberg FR, Hildyard VG: Predictive factors in stroke rehabilitation. Arch Phys Med Rehabil 1974 ; 55 : 545-553

7) Heinemann $\mathrm{AW}$, Linacre JM, Wright BD, Hamilton $\mathrm{BB}$, Granger $\mathrm{C}$ : Prediction of rehabilitation outcomes with disability measures. Arch Phys Med Rehabil 1994; 75 : 133-143

8) Sonoda S, Chino N, Domen K, Saitoh E: Changes in impairment and disability from the third to the sixth month after stroke and its relationship evaluated by an artificial neural network. Am J Phys Med Rehabil 1997; 76 : 395-400

9）才藤栄一, 鈴木美穂 : 脳卒中患者の機能回復と予測. 総 合臨牀 $1998 ； 47: 316-322$

10) Jorgensen HS, Nakayama H, Reith J, Raaschou HO, Olsen TS: Stroke recurrence: predictors, severity, and prognosis. The Copenhagen stroke study. Neurology 1997 ; 48 : 891-985

11) Chae J, Zorowitz RD, Johnston MV: Functional outcome of hemorrhagic and nonhemorrhagic stroke patients after in-patient rehabilitation. Am J Phys Med Rehabil 1996; 75 : 177-182

12) Miller LS, Miyamoto AT: Computed tomography : its potential as a predictor of functional recovery following stroke. Arch Phys Med Rehabil 1979; 60 : 108-109

13）山海知子, 磯 博康, 今野弘規, 大平哲也, 谷川 武, 嶋 本 喬, 北村明彦, 佐藤眞一, 内藤義彦, 木山昌彦, 岡村 智教, 中川裕子, 飯田 稔, 小町喜男: 脳卒中の生命予 後, 機能予後に関疫学的研究. CT 所見を中心とした分 
類を用いた検討. 日本公衛誌 $1998 ； 45 ： 552-563$

14) Chaudhuri G, Harvey RF, Sulton LD, Lambert RW : Computed tomography head scans as predictors of functional outcome of stroke patients. Arch Phys Med Rehabil 1988 ; 69 : 496-498

15) Saeki S, Ogata H, Hachisuka K, Okubo T, Takahashi K, Hosyuyama $T$ : Association between location of the lesion and discharge status of ADL in first stroke patients. Arch Phys Med Rehabil 1994; $75: 858-60$

16) Beloosesky Y, Streifler JY, Burstin A, Grinblat J :
The Importance of brain infarct size and location in predicting outcome after stroke. Age and Ageing $1995 ; 24: 515-518$

17) Hertanu JS, Demopoulos JT, Yang WC, Calhoun WF, Fenigstein HA : Stroke rehabilitation: correlation and prognostic values of computerized tomography and sequential functional assessment. Arch Phys Med Rehabil 1984 ; 65 : 505-508

18) Rumelhart DE, Hinton GE, Williams RJ : Learning representations by back-propagating errors. Nature 1986 ; 323 : 533-536 